\title{
Teachers' Attitude Towards Disabled Students of Distance Learning Departments at Higher Educational Institutions
}

\author{
Movkebayeva Z.A. \\ Abai Kazakh National Pedagogical University \\ Almaty, Kazakhstan \\ zmovkebaewa@mail.ru
}

\author{
Zholtaeva G. N. \\ I. Zhansugurov State University \\ Taldykorgan, Kazakhstan \\ gnzh1661@mail.ru
}

\author{
Khamitova D.S. \\ Abai Kazakh National Pedagogical University \\ Almaty, Kazakhstan \\ momi_91@mail.ru
}

\begin{abstract}
The article discusses the problem of the teacher's readiness for training disabled students of distance learning department at higher educational institutions of the Republic of Kazakhstan. The results of a sociological survey the form of questionnaires and interviews with university teachers are presented in the aim of identifying their motivational, cognitive and methodological readiness to organize educational activities of students with limited mobility. Mostly positive attitude of teachers to disabled students of distance learning departments, positive motivation to improve their own professional qualifications, interest in obtaining the necessary knowledge on the organization of this category students distance learning were revealed. An analysis of the teachers' survey has revealed the presence of certain factors (teaching experience, the experience of teaching students with disabilities and etc.) that affect the formation of their personal attitude to distance learning for students with limited abilities. Along with this, the teachers' survey revealed a lack disabled people psychophysical development of the characteristics understanding, lack of the student perception knowledge with hearing and visual impairments, insufficient understanding of the students with impairments physiological characteristics and so on. The teachers experienced the greatest difficulties in determining the presentation form of the lecture material, monitoring and evaluating independent works of students with problems of hearing, vision and movement. Characteristics were the difficulties associated with the adaptation of educational materials for students with vision and hearing problems. The revealed difficulties in organizing distance learning for disabled students allowed the authors to offer some recommendations for the implementation of this process.
\end{abstract}

Keywords-higher education; inclusive education; disabled students; readiness; distance education.

\section{INTRODUCTION}

In the last decade, the organization of the educational process on distance educational technology is actively developing in Kazakhstani universities. It opens up new prospects for disabled people. Distance learning allows a disabled person to receive a profession in the most convenient way with the use of special technical devices if necessary. Therefore, today the higher educational institution has a very difficult task - the organization of distance learning for students which based on the characteristics of their psychophysical development. It has ensured that they fully master all the necessary professional skills to be as competitive as possible on the labor market. A thorough analysis of technological, substantive, organizational, methodological and other components of the distance educational process is necessary for it. An important study is the readiness for distance learning of all participants in this process, the nature of their interaction, an analysis of the problems and difficulties associated with the specifics of students' psychophysical disorders. Particular attention is required to determine the teachers' willingness, since distance learning for disabled students presents new requirements for their professional activities.

\section{LITERATURE REVIEW}

The study is based on philosophical ideas about the formation and development of the information society $[1,2$, etc.], didactic ideas about the essence of the distance learning process $[3,4,5$, etc.], psychological and pedagogical research related to the education and development of disabled people, including their professional education [6,7,8, etc.]. Foreign and Kazakhstani authors note that for the successful implementation of inclusive education in universities it is necessary that the entire community of higher education institutions be ready for changes in this area. The specifics and problems of obtaining higher and vocational education are revealed in the research works of Sarah Holloway [9], Maureen J. Reed, Deborah J. Kennett, Marc Emond [10] E. F. 
Seeer [11], B.Z. Cantor [12], E.A. Martynova [13], Movkebaeva Z.A. [14], Duzelbaeva A.B. [15], Simanovsky A. E. [16] and others. The authors noted the need for the university to have sufficient funds to meet the individual needs of disabled students and support for their learning. The most effective support in training can be provided by a teacher who has the necessary knowledge and owns practical skills of working with students with various disabilities. In this regard, foreign authors Mary Elizabeth Collins, Carol T. Mowbray, Lynne Kendall $[17,18]$ consider that it necessary to train staff to work with students with various disabilities, to prepare special handouts and materials for them. Researchers have noted some instances of bias on the part of teachers and pointed out the need for special training for all teachers to raise disability awareness. This is also evidenced by studies of Russian and Kazakhstani scientists who note [11-16] that university teachers often do not know how to behave with students with disabilities, they have underestimated ideas about their capabilities, do not have sufficient knowledge of individual and differentiated skills to work with students with different levels of development of hearing, vision and movement.

American and Irish scientists Jennifer Redpath, Patricia Kearney, Peter Nicholl, Maurice Mulvenna, Jonathan Wallace, Suzanne Martin, Allison R. Fleming, Anthony J. Plotner and Kathleen Marie Oertle Oertle [19,20] consider that it necessary to conduct individual consultation sessions throughout studying at a university and providing students with disabilities with all the necessary educational materials (lecture notes and relevant practical materials) before the start of classes.

\section{RESEARCH METHODOLOGY}

The authors organized a sociological survey in the form of questionnaires and interviews with university teachers who implement distance learning for students with disabilities. The aim of the study was to determine the level of teachers readiness for distance learning for students with disabilities.

To achieve this goal, we identified the following tasks:

- to determine the attitude of teachers to distance learning students with disabilities;

- to identify the level of motivational, cognitive and methodological readiness for the implementation of distance learning for students with disabilities.

In accordance with the purpose and objectives of the study, a survey was organized and conducted among teachers of higher educational institutions. 185 university professors took part in the experiment, 75 were male teachers and 110 female teachers. The age of the interviewed teachers is from 23 to 56 and older, work experience varies from 1 year to 31 years and more. In this questionnaire, questions were grouped, which consisted of the following blocks aimed at determining:

- the nature of the teachers motivation to learn, including distance learning, for students with disabilities;

- the theoretical knowledge about the features of the organization of distance learning for students with disabilities;

- the practical skills in organizing distance learning for students with disabilities.

\section{RESULTS}

The results of the questionnaire on the first block of the questionnaire made it possible to identify the nature of motivation and teacher's personal attitude to teaching disabled students by distance learning. Most teachers (58\%) define the distance learning system as the most suitable form of higher education for students with disabilities. A quarter of the teachers surveyed consider that the full-time study is appropriate for them at the university. $14 \%$ of teachers prefer only distance learning for students with disabilities. According to survey only $3 \%$ of the teachers consider evening classes to be the best form for students with disabilities. When analyzing the difficulties most often noted by teachers during distance education of students with disabilities, the following is noted: insufficient knowledge about the features of students with disabilities cognitive activity (25\%), lack of textbooks, teaching aids for working with this category of people $(29 \%)$, lack of practical recommendations on distance learning for students with disabilities at the university $(13 \%)$, problems in assessing students with disabilities (18\%), difficulties in presenting materials to students in accordance with and the violations they have $(8 \%)$, difficulties in selecting materials for the course $(7 \%)$. Teachers experienced certain difficulties in adapting teaching materials to present them in an accessible form for students with visual and hearing impairment. Teachers note the following difficulties in the distance learning for students with disabilities: the selection of time for online classes (22\%), a longer explanation of educational material $(8 \%)$, an insufficient number of teaching aids in the taught disciplines with individual tasks of varying complexity ( $10 \%$ of teachers under the survey), the lack of advice from technical workers on the design and conduct of educational courses on the distance learning platform (17\%), and etc. In the aim of the distance learning quality improvement for students with disabilities in higher educational institutions, respondents noted the need for special training courses $(4 \%)$, the organization of ongoing seminars, round tables $(5 \%)$ and sign language courses (2\%). According to the respondents who participated in this survey, for the effective organization of distance learning for students with disabilities, it is advisable to teach them individually (12\%), together with healthy peers $(16 \%)$, in the form of distance learning $(41 \%)$ and in special groups $(13 \%)$.

The following questionnaire questions and interviews with teachers were divided into three main blocks: motivational, cognitive and methodological. The questions of the first block were aimed at revealing the understanding of the necessity, essence and advantages of distance learning for students with disabilities. The teachers' interest in the implementation of this system and their awareness of the need for distance learning as an affordable form of higher education for students with disabilities were determined. It was revealed that the vast majority of respondents expressed their understanding of the need for distance technologies in teaching students with disabilities and showed interest in their implementation. At the same time, $65 \%$ of respondents indicated that they receive satisfaction from the distance learning process for students with disabilities. Some respondents (32.6\%) consider this process as an opportunity for self-affirmation, raising their status, prestige and respect from others. For another part of respondents $(32.5 \%)$, an important motive for participating in distance learning was to receive high marks from the leadership for work in the distance learning system for students with disabilities. More than half of the respondents $(51.3 \%)$ showed a desire to improve their own professional 
skills in the distance learning system of this category of students (Table 1).

TABLE I. TEACHERS' MOTIVATION TO DISTANCE LEARNING STUDENTS WITH DISABILITIES (\%)

\begin{tabular}{|c|c|c|}
\hline № & Criteria & $\%$ \\
\hline 1 & $\begin{array}{l}\text { Striving for professional growth and self-development in } \\
\text { the process of distance learning of students with } \\
\text { disabilities and disabled students }\end{array}$ & 74,3 \\
\hline 2 & $\begin{array}{l}\text { Interest in the implementation of distance learning system } \\
\text { for students with disabilities and disabled students }\end{array}$ & 68,2 \\
\hline 3 & $\begin{array}{l}\text { Satisfaction from the process of students with disabilities } \\
\text { and disabled students distance learning and the result of } \\
\text { work }\end{array}$ & 65 \\
\hline 4 & $\begin{array}{l}\text { Understanding the need for distance learning technologies } \\
\text { for students with disabilities and students with limited } \\
\text { mobility }\end{array}$ & 64,2 \\
\hline 5 & $\begin{array}{l}\text { Awareness of their activities importance, the need to } \\
\text { create conditions for the training of students with } \\
\text { disabilities and disabled students in order to meet special } \\
\text { educational needs }\end{array}$ & 57,6 \\
\hline 6 & $\begin{array}{l}\text { Striving to achieve professionalism in the system of } \\
\text { students with disabilities and disabled students distance } \\
\text { learning }\end{array}$ & 51,3 \\
\hline 7 & $\begin{array}{l}\text { The desire to receive high marks from the management } \\
\text { for the work in the system of students with disabilities and } \\
\text { disabled students distance learning }\end{array}$ & 32,5 \\
\hline 8 & $\begin{array}{l}\text { Independence in the shaping and solution of pedagogical } \\
\text { problems in the process of distance learning }\end{array}$ & 39,3 \\
\hline 9 & $\begin{array}{l}\text { The desire for self-affirmation, to improve their status, } \\
\text { prestige, the need for respect from others }\end{array}$ & 32,6 \\
\hline
\end{tabular}

The questions of the second, cognitive block are aimed at revealing from teachers of higher educational institutions theoretical knowledge about the distance learning system, the main methods, techniques and technical features of the distance learning organization for students with disabilities. The results of the teachers responses analysis in this block indicate that $64.1 \%$ of respondents have knowledge of distance learning, about half of the respondents (46.3\%) have ideas about the features of organizing independent work in the distance learning system. Describing their own computer and Internet skills, the vast majority of respondents (72.2\%) noted the necessity of a good knowledge of the computer operation principles and auxiliary devices. The vast majority of respondents (with the exception of 1.8\%) indicated that they had good internet skills. Along with this, a significantly smaller number of respondents $(46.8 \%)$ noted their ability to work with software. It is necessary for the implementation of distance learning. Less than half $(46.1 \%)$ of respondents are familiar with the features of the distance learning organization for students with various impairments. Even fewer respondents (34.7) indicate their own knowledge of the features of the distance learning organization for students with hearing and visual impairment. Only $7.5 \%$ of respondents are familiar with the features of working with students with intellectual disabilities.

Information about typical responses of teachers to questions of the second block is presented in Table 2.
TABLE II. COGNITIVE BLOCK - KNOWLEDGE OF THE DISTANCE LEARNING ORGANIZATION FEATURES FOR STUDENTS WITH DISABILITIES $(\%)$

\begin{tabular}{|c|c|c|}
\hline № & Criteria & $\%$ \\
\hline 1 & Knowledge of the distance learning system concept & 64,1 \\
\hline 2 & $\begin{array}{c}\text { Knowing of the problems that are solved in the process of } \\
\text { distance learning }\end{array}$ & 58,1 \\
\hline 3 & $\begin{array}{l}\text { Knowing of methods and techniques that are used by the } \\
\text { teacher in the process of distance learning }\end{array}$ & 61,2 \\
\hline 4 & $\begin{array}{l}\text { Knowing features of students with different disabilities of } \\
\text { the distance learning organization }\end{array}$ & 46,1 \\
\hline 5 & $\begin{array}{l}\text { Knowing of the features of the organization of distance } \\
\text { learning with students with limited mobility }\end{array}$ & 43,2 \\
\hline 6 & $\begin{array}{l}\text { Knowing of the features of the organization of distance } \\
\text { learning of students with hearing impairment }\end{array}$ & 34,7 \\
\hline 7 & $\begin{array}{l}\text { Knowing of features of the organization of distance } \\
\text { learning of students with visual impairment }\end{array}$ & 34,7 \\
\hline 8 & $\begin{array}{l}\text { Knowing of features of the organization of distance } \\
\text { learning of students with speech disorders }\end{array}$ & 61,2 \\
\hline 9 & $\begin{array}{l}\text { Knowing of features of the organization of distance } \\
\text { learning of students with intellectual disabilities }\end{array}$ & 7,5 \\
\hline 10 & $\begin{array}{l}\text { Knowing of the peculiarities of the organization of } \\
\text { independent work and interaction in the system of } \\
\text { distance learning }\end{array}$ & 46,3 \\
\hline 11 & $\begin{array}{l}\text { Knowing of the principles of computer and auxiliary } \\
\text { devices }\end{array}$ & 72,2 \\
\hline 12 & Ability to work on the Internet. & 98,2 \\
\hline 13 & $\begin{array}{l}\text { Ability to work with the software necessary for the } \\
\text { implementation of distance learning }\end{array}$ & 46,8 \\
\hline 14 & $\begin{array}{l}\text { Knowledge of the features and possibilities of interactive } \\
\text { forms of education }\end{array}$ & 43,2 \\
\hline
\end{tabular}

The third block of the questionnaire questions contributed to the identification of methodological skills among teachers on the practical use of the distance learning system. The results of the teachers' answers to the questions in this block are presented in Table 3. An analysis of the respondents ' answers indicates that they have no serious difficulties in planning their activities in the distance learning system for students with disabilities $(63.2 \%)$, forecasting the expected results $(46.5 \%)$, and drawing up individual curricula $(35.7 \%)$. Along with this, less than half of the respondents (44\%) indicated their own ability to use various forms of monitoring the knowledge of students with disabilities in the distance learning system. Describing the practical skills of working with a computer and on the internet, it is worth noting that $95.6 \%$ of respondents have no problems in using e-mail, the majority of teachers surveyed $(74.6 \%)$ are able to work in chat, $83.5 \%$ of teachers are able to conduct video communication in programs such as Skype, and only $66.7 \%$ of respondents can work and conduct their subjects through online conferences. Despite the respondents ' technical skills and working skills in the distance learning system, only $33.2 \%$ of respondents are able to provide psychological, pedagogical support to students with disabilities in the distance learning system. 
- organization of regular individual consultations: a speech

TABLE III. PRACTICAL SKILLS IN ORGANIZING DISTANCE LEARNING FOR STUDENTS WITH DISABILITIES. (\%)

\begin{tabular}{|c|c|c|}
\hline № & Criteria & $\%$ \\
\hline 1 & Ability to use e-mail & 95,6 \\
\hline 2 & Ability to go to Skype & 83,5 \\
\hline 3 & Ability to conduct a conference with other students & 75,5 \\
\hline 4 & Ability to work in chat & 74,6 \\
\hline 5 & Ability to participate in Internet conferences & 66,7 \\
\hline 6 & $\begin{array}{l}\text { Planning of their activities in the system of distance } \\
\text { learning of students with limited mobility }\end{array}$ & 63,2 \\
\hline 7 & $\begin{array}{l}\text { Regularly predict expected results from distance learning } \\
\text { systems for students with disabilities and disabled } \\
\text { students }\end{array}$ & 46,5 \\
\hline 8 & $\begin{array}{l}\text { Use different forms of knowledge control of students with } \\
\text { disabilities in the distance learning system }\end{array}$ & 44,2 \\
\hline 9 & $\begin{array}{l}\text { Possession of methods of organization of network } \\
\text { interaction of subjects of distance learning: }\end{array}$ & 42,2 \\
\hline 10 & $\begin{array}{l}\text { Possibility of drawing up individual curricula for distance } \\
\text { learning of students with hearing impairment }\end{array}$ & 35,7 \\
\hline 11 & $\begin{array}{l}\text { Ability to make individual curricula for distance learning } \\
\text { of visually impaired students }\end{array}$ & 35,7 \\
\hline 12 & $\begin{array}{l}\text { Ability to make individual curricula for distance learning } \\
\text { of students with speech disorders }\end{array}$ & 35,7 \\
\hline 13 & $\begin{array}{l}\text { Ability to make individual curricula for distance learning } \\
\text { of students with limited mobility }\end{array}$ & 35,7 \\
\hline 14 & $\begin{array}{l}\text { Ability to provide pedagogical psychological } \\
\text { technological support to students with disabilities in the } \\
\text { conditions of distance learning }\end{array}$ & 33,2 \\
\hline 15 & $\begin{array}{l}\text { Ability to fill modules on disciplines with educational } \\
\text { material for students with disabilities and disabled } \\
\text { students in the process of distance learning }\end{array}$ & 33,2 \\
\hline 16 & $\begin{array}{l}\text { Ability to make individual curricula for distance learning } \\
\text { of students with intellectual disabilities }\end{array}$ & 21,5 \\
\hline
\end{tabular}

\section{DISCUSSION}

The results of the research indicate the need for a comprehensive solution to existing problems in the organization of distance learning for students with disabilities, as well as taking into account the characteristics of the psychophysical development of students and individual selection of the necessary teaching methods and techniques. According to the survey, it is advisable to conduct the following activities to implement effective distance learning education:

- development of practical recommendations for teachers on the organization of distance learning for students with disabilities, taking into account the types and severity of their disabilities;

- conducting trainings to expand the teachers' competence on the specific features of hearing and visual perception, attention and other mental processes of student's personal disabilities;

- conducting special courses to expand the university teachers' competence in the field of distance learning education;

- accompaniment of the distance learning educational process with the help of a sign language interpreter and a specialist tutor among special teachers with experience working for people with disabilities;

- providing disabled students with all the necessary educational materials (lecture notes and relevant practical materials) before the start of classes. therapist, defectologist, typhlopedologist, sign teacher, psychologist, social educator, neurologist and etc.

The study was carried out in the framework of the Ministry of Education and Science of the Republic of Kazakhstan project No. AR05134037 "Formation of the distance educational environment of a university for the training of students (invalids) with disabilities".

\section{CONCLUSION}

The study shows teachers' positive attitude towards teaching students with disabilities. They have mostly positive motivation to improve their own professional qualifications. They have also interest in obtaining the necessary knowledge on the organization of distance learning for this category of students. Along with this, the teachers revealed a lack of understanding of the characteristics of the psychophysical development of people with disabilities, lack of knowledge of the perception of students with hearing and visual impairments, insufficient understanding of the student invalids physiological characteristics, and etc. The teachers experienced the greatest difficulties in determining the presentation form of the lecture materials, monitoring and evaluating independent works of students with hearing, vision and movement problems. Characteristic were the difficulties associated with the adaptation of educational materials for students with vision and hearing problems. Teachers of higher educational institutions experienced serious difficulties in determining the form of lecture material presentation, the selection of teaching methods and means for organizing and monitoring the implementation of independent practical work for students with disabilities. In addition to the incomplete correspondence of the indicated pedagogical skills for the training of students with disabilities, university teachers revealed insufficiently formed skills in providing the psychological support necessary for students, as well as certain gaps in the technical skills necessary for working in the distance learning system.

\section{References}

[1] Selivanova Yu. V. and Shchetinina E. B. teachers "Readiness to teach students with disabilities", Siberian pedagogical journal. 2017, 2, pp. 6570 .

[2] Liudmila M. Volosnikova and Galina Z. Efimova, Faculty Attitudes Towards Students with Disabilities in Russian Universities, "A Glance at Western Siberia", The European Proceedings of Social \& Behavioural Sciences. 2016, pp.432-438.

[3] Selivanova Yu. V., "Studying the attitude of University teachers to teaching students with disabilities", Dylewskie reading "Sociological diagnosis of modern society". Saratov. pp. 430-436.

[4] Jennifer M. Cassady "Teachers' Attitudes Toward the Inclusion of Students with Autism and Emotional Behavioral Disorder Electronic Journal for Inclusive" Education Vol. 2 Number 7 Electronic Journal for Inclusive Education. 2011, vol. 2, 7, 23.

[5] Ross-Hill, R. "Teacher attitudes towards inclusion practices and special needs students". Journal of Research in Special Educational Needs. 2009, 9(3), pp. 188-198.

[6] Williamson, P. T. (2000). "Attitudes of the Troy State University Dothan faculty toward students with disabilities" (Doctoral dissertation, Auburn University. 2000). World Cat, OCLC: 44857670.

[7] Bashir Abu-Hamour "Faculty Attitudes toward SD in a Public University in Jordan”. International Education Studies. 2013, vol. 6, 12; 2013.

[8] Kelsey K. McNamee "A Survey of Preservice Teachers' Attitudes on Integrating Students with Disabilities in Inclusive Education Classrooms", University of Central Florida. 2016, 33. 
[9] Sarah Holloway (2001) "The Experience of Higher Education from the Perspective of Disabled Students, Disability \& Society". 2016, 4, pp. 597-615. DOI:10.1080/09687590120059568)

[10] Maureen J Reed, Deborah J Kennett and Marc Emond "The influence of reasons for attending university on university experience: A comparison between students with and without disabilities", Active Learning in Higher Education. 2015, vol. 16(3), pp. 225 -236

[11] Zeer E. F., "Methodology the professional development of the personality", Ekaterinburg: Russian State Vocational Pedagogical University Publ. 2014, pp. 194.

[12] Kantor V. Z., "Rehabilitation potential of persons with disabilities: the problem of system of pedagogical analysis". Special education. 2012, 1, pp. 44-53.

[13] Martynova E. A., "Information educational environment for students with disabilities in Chelyabinsk state University", Chelyabinsk. 2012, pp. 253-257.

[14] Movkebayeva Z., Oralkanova I., Mazhinov B., Beisenova A. and Belenko O., "Model of Formation for Readiness to Work within Inclusive Education in Teachers", International journal of environmental \& science education 2016, vol. 11, 11, pp. 4680-4689

[15] Movkebayeva Z., Kabdyrova A., Duzelbayeva A., Denissova I. and Tynybayeva L., "Students attitude towards co-education with disabled people in higher education institutions", Journal of Entrepreneurship Education. 2017, vol. 20, 3, pp. 1-11.

[16] Simanovsky A. E. "The use of distance learning technologies for students with disabilities", Yaroslavl pedagogical Bulletin. 2012, 4, vol. II (Psychological and pedagogical Sciences)

[17] Mary Elizabeth Collins, "Higher Education and Psychiatric Disabilities: National Survey of Campus Disability Services", American Journal of Orthopsychiatry 2005 , vol. 75,2 , pp. $304-315$

[18] Lynne Kendall, "Higher education and disability: Exploring student experiences", Cogent Education. 2016, 3, 1256142. URL: http://dx.doi.org/10.1080/2331186X.2016.1256142

[19] Jennifer Redpath, Patricia Kearney, Peter Nicholl, Maurice Mulvenna, Jonathan Wallace and Suzanne Martin/, "Studies in Higher Education". 2013, vol. $38, \quad 9, \quad$ pp. 1334-1350. URL: http://dx.doi.org/10.1080/03075079.2011.622746

[20] Allison R. Fleming, Anthony J. Plotner and Kathleen Marie Oertle "College Students with Disabilities: The Relationship Between Student Characteristics, the Academic Environment, and Performance", Journal of Postsecondary Education and Disability. 30(3), pp.209-221. 